\title{
Adolescence in the Kibera slums of Nairobi, Kenya
}

\author{
Annabel Erulkar \\ Population Council \\ James K. Matheka \\ Population Council
}

Follow this and additional works at: https://knowledgecommons.popcouncil.org/departments_sbsr-pgy

Part of the Demography, Population, and Ecology Commons, Family, Life Course, and Society Commons, Inequality and Stratification Commons, International Public Health Commons, and the Medicine and Health Commons How does access to this work benefit you? Let us know!

\section{Recommended Citation}

Erulkar, Annabel and James K. Matheka. 2007. "Adolescence in the Kibera slums of Nairobi, Kenya." Nairobi: Population Council. 


\section{Adolescence in the Kibera Slums of NaIrobi KenYa}





\section{Adolescence in the Kibera Slums of Nairobi, Kenya}

Annabel S. Erulkar

James K. Matheka 


\title{
(1) Population Council
}

The Population Council is an international, nonprofit, nongovernmental organization that seeks to improve the well-being and reproductive health of current and future generations around the world and to help achieve a humane, equitable, and sustainable balance between people and resources. The Council conducts biomedical, social science, and public health research and helps build research capacities in developing countries. Established in 1952, the Council is governed by an international board of trustees. Its New York headquarters supports a global network of regional and country offices.

(C) 2007 by The Population Council

Population Council
P.O. Box 17643
Nairobi, Kenya
Tel: (254) 20-2713480/1/2/3
Fax: (254) 20-213479

\author{
Population Council \\ One Dag Hammarskjold Plaza \\ New York, NY 10017 USA \\ Tel: $212-339-0500$ \\ Fax: 212-755-6052 \\ http://www.popcouncil.org
}

Annabel S. Erulkar, PhD is Senior Associate and Country Director at the Population Council's Ethiopia Office in Addis Ababa, Ethiopia.

James Matheka is Program Coordinator at the Population Council's office in Nairobi, Kenya.

Photo credits: C2007 Sean Hawkey, Courtesy of Photoshare

\section{ACKNOWLEDGEMENTS}

This study would not have been possible without the support and guidance of a great many institutions and individuals. We gratefully acknowledge the support of Nike Foundation for making this study possible. We appreciate the assistance of the local administration in Kibera and the Kenya Central Bureau of Statistics (CBS). Carolina for Kibera (CFK), KICOSHEP, and Kibera Transformation Development Trust assisted with recruitment and sensitization on the study. CFK also provided us with space for interviewer meetings. Nicole Haberland and Judith Bruce gave us very helpful comments on earlier versions of this report. Finally, we thank the young people themselves who were so giving of their time, ideas and experiences and from whom we have learned a great deal about what it means to be an adolescent in Kibera, Kenya. 


\section{TABle of Contents}

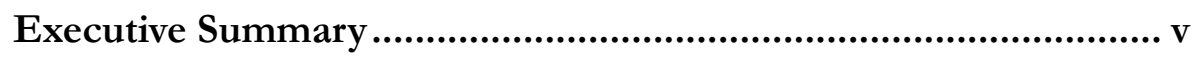

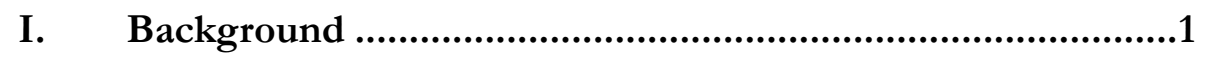

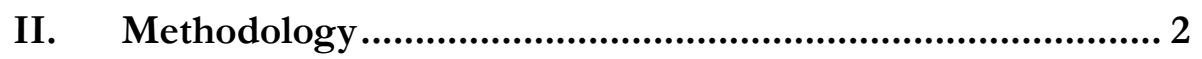

III. Sample Characteristics .................................................... 4

IV. Parental Survivorship \& Co-residence ............................... 6

V. Migration ..................................................................... 7

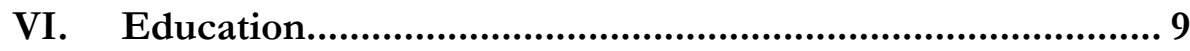

VII. Livelihoods....................................................................10

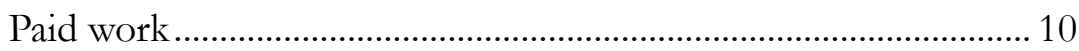

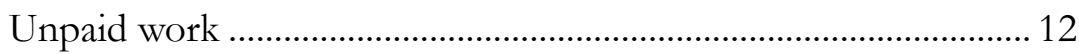

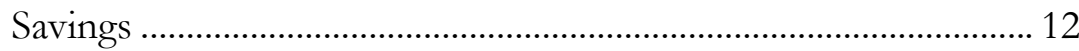

VIII. Social Support, Safety Nets \& Sense of Well-Being ............13

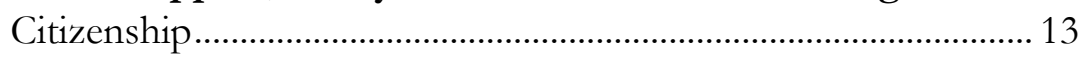

Sense of well-being ........................................................................ 13

Social support \& safety nets ............................................................. 14

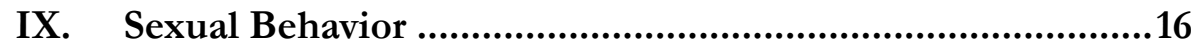

X. Marriage \& Attitudes Related to Marriage .........................18

Context of marriage ........................................................................ 18

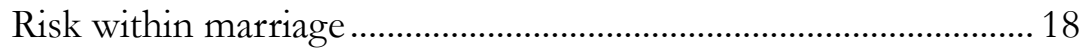

Attitudes about marriage.............................................................. 20

XI. HIV/AIDS, Reproductive Health \& Family Planning ........21

Knowledge of HIV/AIDS \& STIs................................................ 21

Family planning knowledge and use................................................. 22

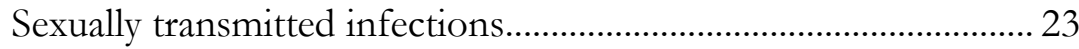

Experience with HIV/AIDS ............................................................... 23

XII. Pregnancy \& Childbearing ............................................... 24

XIII. Discussion \& Implications for Programs........................... 25

Recognize the diversity of young people.......................................... 25

Create safety nets, addressing personal security and

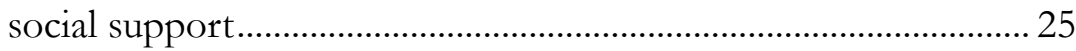

Address lack of power and agency in sexual relationships........... 26

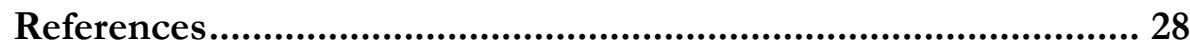




\section{TABLES}

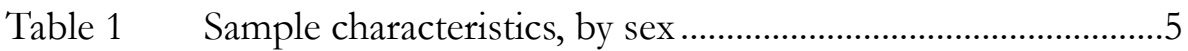

Table 2 Parental survivorship and residence, by sex.............................6

Table 3 Patterns of migration among adolescents, by sex ....................

Table 4 Age of school entry, educational attainment \& reason for leaving school, by sex ............................................................

Table 5 Patterns of paid work among adolescents, by sex ................ 11

Table 6 Sense of well -being in the community, by sex...................... 14

Table 7 Social support and networks in the community, by sex ...... 15

Table 8 Self esteem, by sex ............................................................... 16

Table 9 Relationship to and age difference with first sexual partner, by sex ............................................................................ 16

Table 10 Context of first sexual experience, by sex............................. 17

Table 11 Conditions of marriage among girls ...................................... 18

Table 12 Risk taking and infidelity within marriage .............................. 19

Table 13 Percent of respondents holding conservative views related to marriage, by sex (percentage agreeing with the statement)

Table 14 HIV/AIDS and RH knowledge, by sex

Table 15 Knowledge of family planning methods, by sex

Table 16 Ever use of family planning methods, by sex 22

Table 17 Experience with HIV/AIDS and knowledge and exposure to VCT, by sex

Table 18 Context of girls' first birth 24 


\section{Executive Summary}

Rates of urbanization in Kenya are among the highest in the world and young people form a large proportion of those moving from rural to urban areas of the country. For many young people, the first point of entry into urban areas are the slums. Kibera slums in Nairobi are said to be one of the largest and oldest slums in Africa. Adolescents and young people make up a significant proportion of the slum-dwelling population, yet little is known about their experiences growing up in these poor urban environments. This population-based study of adolescents took place in the Kibera slum in Nairobi, Kenya, in 2006. One thousand six hundred seventy five adolescent boys and girls aged 10 to 19 were interviewed in four of 16 villages in Kibera. Girls were significantly more likely to be out of school than boys, and had lower educational attainment than did boys. Sixteen percent of girls were married.

Migration and living arrangements: Roughly half of the adolescents had migrated into Nairobi from other regions, especially rural areas. Boys were more likely to move during early childhood (below the age of ten), most often with parents; girls were more likely to migrate during later adolescence and less often with parents, but rather with other relatives, on their own, or with boyfriends and spouses. Fewer than 50 percent of adolescent boys and girls lived with both parents. Girls were significantly more likely than boys to live with neither parent; 27 percent of girls lived with no parent versus 15 percent of boys.

Livelihoods: One quarter of boys and 14 percent of girls had worked for pay. Boys are engaged in a much wider range of job types than girls. Boys were working as construction workers, tradesmen, porters in carrying heavy loads, and as hawkers. On the other hand, the vast majority of working girls were engaged in domestic work. Among working girls, 49 percent were in domestic work, underscoring that girls seem to have fewer work options available to them compared to boys. In addition, girls were also engaged in significantly more unpaid domestic work than boys.

Social networks, safety nets and sense of well-being: Among older adolescents in the sample, considerably fewer girls than boys had a Kenyan national identity card (38 percent of boys and 27 percent of girls). Girls were significantly more likely to feel ill at ease in their surroundings, with 60 percent of girls saying they are scared of being raped; 47 percent describing that they are scared of someone in their neighborhood; and 30 percent reporting that they are teased in their neighborhood. Likewise, girls had far fewer safety networks in the community compared to boys. Only 25 percent of girls reported having a "safe space" in their community to meet other girls, compared to 58 percent of boys. Only 40 percent of girls had a non-familial adult in their community to whom they could turn, compared to 53 percent of boys. Thirty-eight percent of girls had a place to stay if they needed one, compared to 51 percent of boys.

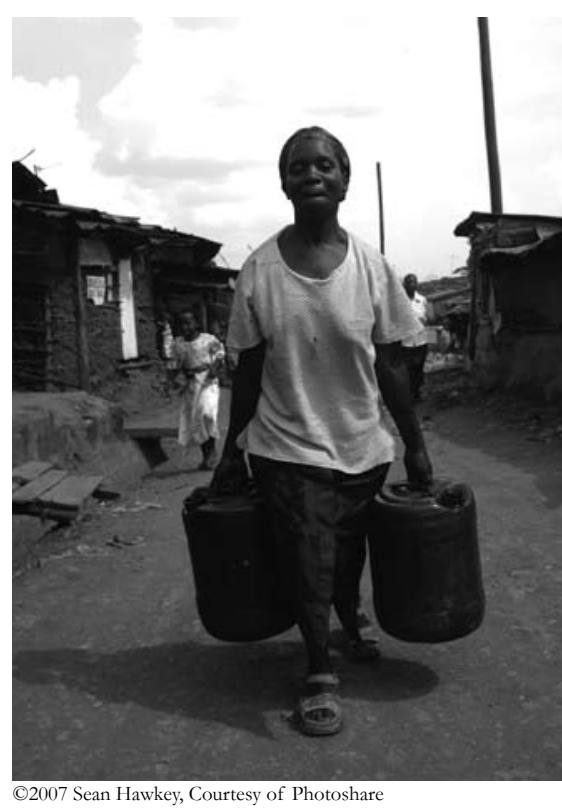


Sexual behavior: Among unmarried adolescents, 31 percent of boys and 24 percent of girls were sexually experienced. A considerable proportion of girls did not want to have sex at the time they did (34 percent did not want sex and 32 percent were undecided). Forty-three percent of girls experienced coerced or forced first sex, including their partner not taking 'no' for an answer, threats, money/gifts, or physical force. Coerced girls experienced sexual relations at significantly younger ages and with significantly older partners, compared to girls for whom sex was consensual.

Marriage: Sixteen percent of adolescent girls were married, with most marriages having been chosen, and not arranged. A large percentage of married girls reported that their spouses had been unfaithful or were unsure about their spouses' fidelity (32 percent). One out of six married girls had been hit or beaten in the last three months and fully 37 percent of girls reported that they worried that their husbands would give them HIV.

Reproductive health \& HIV/AIDS: About one quarter of adolescents had a family member who had died of AIDS. Most young people knew where to go for VCT (73 percent of boys and 68 percent of girls) and more girls than boys reported having had the test (14 percent of boys, 29 percent of girls). Among young people who had wanted VCT but never had, the main barrier was fear of the result, among 29 percent of respondents. After that, 10 percent did not know where to get the test and 10 percent said they had no time.

Pregnancy \& childbearing: Sixteen percent of girls have had children, mostly among married girls. At the same time, the pregnancies were most often not wanted at that time; only 27 percent of pregnancies were desired and 63 percent were not wanted at the time. Most births took place in a hospital or clinic and were attended by a medical professional.

Programmatic implications: The majority of programs for young people and adolescents in sub-Saharan Africa are gender blind and generic. This research underscored the special circumstances of adolescents in informal settlements, a group for which there is no specialized programming. In addition, even within this population, there is a remarkable diversity of young people. Many young people are living with no parents or in single parent households. Some are in school; some are working (including as domestic workers); some are married; some have children. Programs need to take into account the diversity of young people and program for subgroups of adolescents, rather than for a generic vision of adolescents. Many young people described having witnessed violence. Young women have experienced high degrees of coercion, rape and domestic violence. Mechanisms to establish safe spaces and safety nets, including access to mentors and other means of social support, need to be established. 


\section{BACKGROUND}

Kenya has one of the highest rates of urbanization in the world; in 1990, 24 percent of Kenyans lived in urban areas, but by 2000, that figure had risen to 33 percent, with Nairobi growing by over 7 percent per year (Garenne, 2003). It is anticipated that Nairobi, with a population of over two million, will increase by five million residents in the next 15 years, most of whom live in low income and 'informal settlements,' as the slum areas of the city are called (Zulu et. al, 2000). The term 'informal settlements' underscores their non-permanence and implicitly justifies the lack of infrastructure and services, including water, electricity, health services, and law enforcement. Here, living conditions are deplorable, with toilets in short supply, safe water unavailable, and garbage collection virtually nonexistent. Housing is extremely poor, with many residents living in oneroom houses made of semi-permanent materials such as mud, wooden planks or metal sheets. Over 50 percent of the population is living below the poverty line (APHRC, 2002), with residents eking out sustenance in whatever manner they can, especially in informal sector activities, such as petty trade or casual labor.

It is in this setting that many adolescents make their transition to adulthood; in fact, increasingly, economically active young men and women are dominating urban areas in Africa (APHRC, 2002). In addition to adolescents who are born in the slums, Africa's largest cities attract migrants from rural areas, especially those in search of education and livelihood opportunities. While there is increasing interest in informal urban settlements, few studies have focused on the adolescent experience in these environments. Similarly, youth programs are being implemented in these areas, often with little understanding of the circumstances and needs of the young people they target.

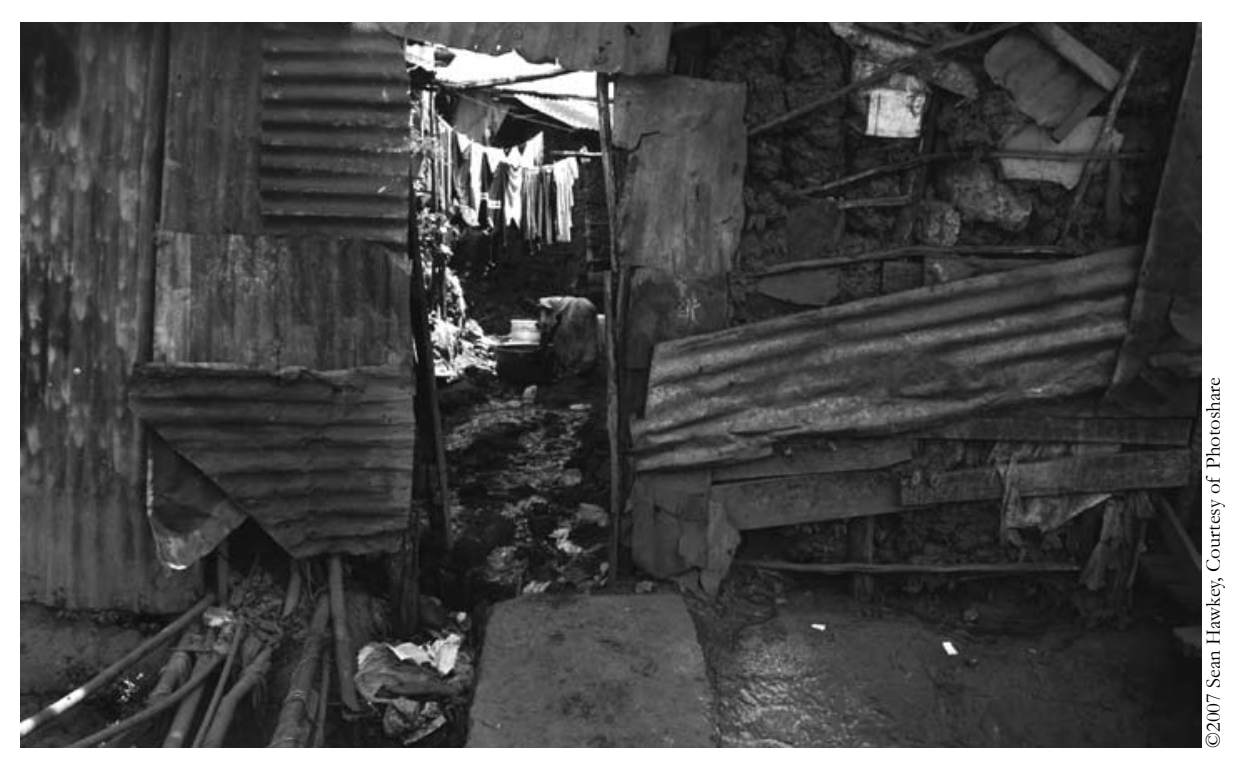


This study explores the adolescent experience in one of Africa's largest slum areas, Kibera, in Nairobi, Kenya. The study examines the experience of adolescents aged 10 to 19, with emphasis on understanding how different groups of young people experience life in these settings. The findings are meant to build a nuanced picture of adolescence in urban slum areas, and to contribute to context-appropriate programming for these young people.

\section{Methodology}

Data for this study is from a population-based survey of adolescents aged 10 to 19 conducted in Nairobi in 2006. The survey took place in the Kibera slum of Nairobi, which is the world's oldest and second largest slum settlement. Kibera slum lies on the southeast corner of Nairobi and is composed of 10 sub-locations, sub-divided into multiple "villages." The population figures for Kibera range widely, from 500,000 to 1,000,000, and it is estimated that one in four Nairobi residents reside here. The settlement covers an area of about 2 square kilometers, roughly the size of New York's Central Park. A railroad track runs through the center of Kibera, which is commonly considered a boundary separating the poorest and most dangerous parts of Kibera below the tracks, from the relatively "better off" parts of Kibera above the tracks. Kibera is home to multiple ethnic groups, who tend to dominate within specific villages.

The study was conducted in four sub-locations, chosen to reflect the various ethnic groups residing in Kibera. Two sub-locations were selected below the railroad tracks (Gatwekera and Laini Saba); one above (Makina), and one sub-location that is dissected by the tracks (Kibera sub-location). Each sub-location is divided into enumeration areas (EA's) by the Kenya Central Bureau of Statistics (CBS). Thirty enumeration areas in each of the four sub-locations were selected, using a random number function available in SPSS. All households in selected EA's were listed, collecting basic demographic information on all members of the household, regardless of age. A household was considered eligible for survey if it had an adolescent member aged 10 to 19. Eligible households were entered into the computer and 2,000 households were selected at random, 500 from each of the four sub-locations. Where a household had more than one adolescent aged 10 to 19, a Kish grid (Kish, 1965) was used to select just one adolescent.

The questionnaire used in the survey was a mostly close-ended, structured instrument. Topic areas covered in the questionnaire were wide ranging, including household composition and assets, educational attainment, time use, social networks and mobility, migration, attitudes and expectations, reproductive health $(\mathrm{RH})$ knowledge and practice, marriage, pregnancy and childbirth and sexual activity. In addition, specific questions, especially 
those for which prior research was limited, were asked in an open-ended format. The questionnaire was translated into Kiswahili and back translated to ensure accuracy.

Survey interviewers had prior interviewing experience and were selected to be young enough so as to make respondents comfortable, ranging in age from 24 to 30 years. Almost all interviewers were residents of Kibera. During the five-day training, interviewers reviewed the questionnaire item by item, and engaged in practice and mock interviews. For open-ended questions, interviewers were trained to probe respondents and record the response verbatim. Toward the end of the training, interviewers practiced the questionnaire on adolescents who resided outside the study area. Male interviewers interviewed male respondents, while females interviewed females. Interviewers paid up to three visits to locate and interview the sampled adolescent.

Informed consent was obtained from all respondents. In addition, informed consent was obtained from parents or guardians of adolescents when they had resident parents or guardians. Supervisors checked all completed questionnaires for data quality and completeness. Data was entered using Epi-data and later converted to SPSS for analysis, with sample weights applied prior to analysis. Descriptive analysis was conducted and all analysis was disaggregated by sex of the respondent. Most results are presented separated by sex, but where no difference exists, results are presented in the aggregate. Where there are discrepancies in the number of responses used in analysis as reflected in tables, this is largely due to missing responses for some variables. Direct quotes from open-ended questions were translated into English and typed into a Word file. These responses were analyzed qualitatively, with issues and patterns identified in the responses and illustrative quotes presented to reflect the most common patterns.

\section{Map of Kibera, Nairobi}

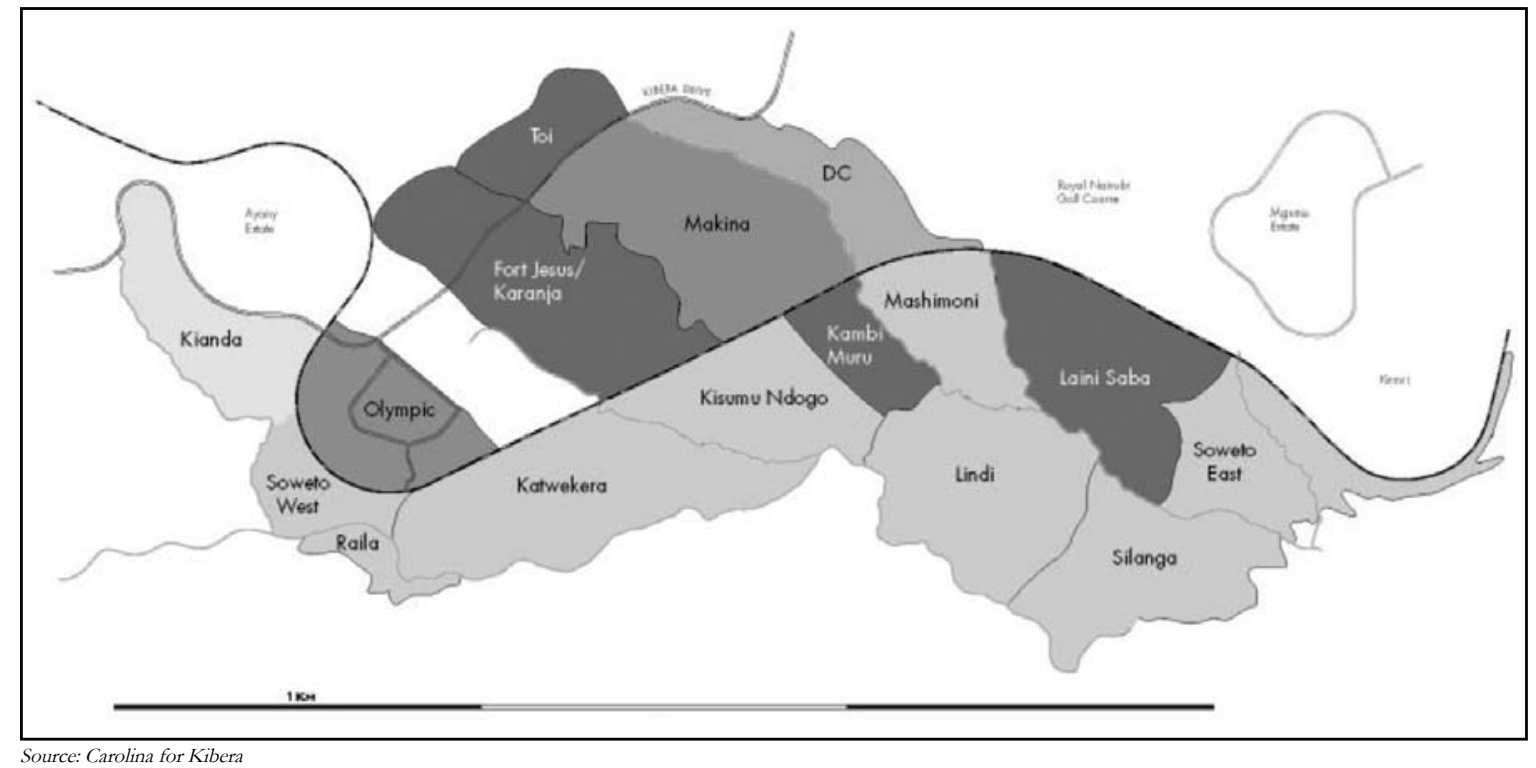




\section{Sample Characteristics}

A total of 1,675 adolescents aged 10 to 19 were interviewed, reflecting a response rate of 84 percent. More girls than boys were interviewed, with the greater number of girls likely a reflection of the larger female population in the study areas. In all, 1,758 girls were listed compared to 1,336 boys, a ratio of 1.3 girls for every boy.

Girls were more likely to be out of school compared to boys, with 43 percent of the female sample not attending school, compared to 29 percent of boys. At the same time, the female sample was slightly older than the male sample. Adolescent girls were more likely to be married than boys. Sixteen percent of girls were ever-married compared to only 2 percent of boys. A considerable proportion of both boys and girls had migrated into Nairobi from another region, roughly 50 percent. On average, households of adolescents were composed of 4.8 members. Slum dwelling adolescents lived in extremely crowded conditions. On average, four household members shared the same sleeping room.

Socio-economic status was measured using an index of household possessions derived from the Demographic and Health Surveys (DHS). Twelve items or amenities were read and respondents were asked if their household possessed such items. Each respondent was scored as to how many of the amenities were present in the household. At the same time, measurement of household-level socio-economic status may be flawed, especially in cases where ones household is the employer's household, as in the case of live-in domestic workers. 
Table 1: Sample characteristics, by sex

\begin{tabular}{|c|c|c|c|}
\hline & & Boy $(n=754)$ & Girls $(n=921)$ \\
\hline \multirow[t]{2}{*}{ Age category } & 10 to 14 & 49.4 & $43.2^{\star *}$ \\
\hline & 15 to 19 & 50.6 & 56.8 \\
\hline \multirow[t]{2}{*}{ School status } & In school & 71.2 & $57.2^{\star * \star}$ \\
\hline & Out of school & 28.8 & 42.8 \\
\hline \multirow[t]{3}{*}{ Educational attainment } & No education & 0.7 & 1.2 \\
\hline & 1 to 8 years & 76.7 & 75.3 \\
\hline & 9 or more years & 22.6 & 23.5 \\
\hline \multirow[t]{2}{*}{ Marital status } & Never married & 98.5 & $84.2^{\star \star \star}$ \\
\hline & Ever married/cohabited & 1.5 & 15.8 \\
\hline \multirow[t]{7}{*}{ Ethnicity } & Kikuyu & 7.9 & $6.4^{* \star *}$ \\
\hline & Luo & 34.9 & 35.4 \\
\hline & Nubian & 11.6 & 9.1 \\
\hline & Kamba & 7.5 & 10.3 \\
\hline & Luyia & 26.5 & 32.5 \\
\hline & Kisii & 6.4 & 2.2 \\
\hline & Other & 5.2 & 4.1 \\
\hline \multirow[t]{4}{*}{ Religion } & Protestant/Other Christian & 57.3 & 56.0 \\
\hline & Catholic & 25.0 & 29.6 \\
\hline & Muslim & 15.5 & 11.7 \\
\hline & Other & 2.2 & 2.7 \\
\hline \multirow[t]{4}{*}{ Area of residence } & Makina & 21.6 & 28.6 \\
\hline & Kibera & 24.2 & 23.3 \\
\hline & Gatwekera & 28.7 & 22.3 \\
\hline & Laini Saba & 25.5 & 25.8 \\
\hline \multirow[t]{2}{*}{ Migrated to Nairobi } & No & 47.4 & $52.7^{* *}$ \\
\hline & Yes & 52.6 & 47.3 \\
\hline \multirow[t]{2}{*}{ Socio-economic status } & Low (0 to 5 amenities) & 44.9 & 47.1 \\
\hline & High (6 to 12 amenities) & 55.1 & 52.9 \\
\hline
\end{tabular}

Differences between groups significant at ${ }^{*} p<0.05 ;{ }^{* *} p<0.01 ;{ }^{* * *} p<0.001$ 


\section{Parental Survivorship \& Co-Residence}

Girls were significantly more likely than boys to have both parents dead and also to live with neither parent. Eight percent of girls were double orphans compared to 5 percent of boys. Seventy one percent of adolescents had both parents alive. A minority of adolescents lived in two-parent households: 49 percent of boys and 45 percent of girls. Fully 27 percent of girls lived with neither parent, compared to 15 percent of boys, a difference that was statistically significant. Adolescents who lived on their own or with only their mother had lower scores on the socioeconomic index scale compared to young people who lived with both parents or their father. Girls living on their own had the lowest mean number of household amenities or possessions.

That such a large proportion of adolescents are not living with parents has implications for youth programs, many of which focus on parent-child communication. These findings reveal that many adolescents in slum areas do not have resident parents, making such approaches inappropriate. Not all adolescents' parents were married to each other; 7 percent of adolescents had parents who were divorced while 3 percent had parents who were never married to each other.

Table 2: Parental survivorship and residence, by sex

\begin{tabular}{llcc}
\hline & & Boy (n=748) & Girls (n=908) \\
\hline Parental survival & Both parents alive & 71.8 & 70.3 \\
& One parent dead & 23.4 & 21.3 \\
& Both parents dead & 4.8 & $8.4^{* *}$ \\
Parental co-residence & & & \\
& Both parents & 49.4 & 44.6 \\
& Mother only & 20.2 & 22.0 \\
& Father only & 15.2 & 6.4 \\
& Neither parent & 15.2 & $27.0^{* * *}$ \\
\hline
\end{tabular}

Differences between groups significant at ${ }^{*} p<0.05 ;{ }^{* *} p<0.01 ;{ }^{* * *} p<0.001$ 


\section{Migration}

Fifty percent of adolescents originated from another region in Kenya, with more boys than girls having migrated (53 percent of boys; 47 percent of girls). Among migrants, most young people came from Nyanza (40 percent of migrants) or Western Provinces (30 percent). Most migrants originated from rural areas of the country, with 76 percent of boys and 63 percent of girls reporting a rural origin.

Table 3: Patterns of migration among adolescents, by sex

\begin{tabular}{llcc}
\hline & & Boy (n=314) & Girls (n=442) \\
\hline \multirow{2}{*}{ Age at migration } & Less than 10 years & 34.2 & 18.8 \\
& Age 10 to 14 & 33.6 & 28.6 \\
& Age 15 to 19 & 32.2 & $52.6^{* * *}$ \\
Person(s) with & No one & 11.5 & 15.9 \\
whom respondent & Parents & 54.2 & $38.7^{* * *}$ \\
moved to Nairobi ${ }^{\text {a }}$ & Grandparent, uncle, aunt & 13.1 & 16.0 \\
& Spouse, boyfriend & 0.0 & $5.7^{*}$ \\
& Other relative & 23.8 & 21.5 \\
& Employer & 0.0 & $1.4^{* *}$ \\
& Other & 3.3 & 1.9 \\
Main reason for & & & \\
migration & Education or vocational training & 40.8 & 39.5 \\
& Accompanied parents & 23.2 & 18.7 \\
& Work & 16.6 & 18.2 \\
& Family problems & & \\
& Accompanied spouse & 10.9 & 8.7 \\
& Other & 0.6 & 6.6 \\
& & 7.9 & 8.3 \\
\hline
\end{tabular}

Differences between groups significant at ${ }^{*} p<0.05 ;{ }^{* *} p<0.01 ;{ }^{* * *} p<0.001$

aPercentages may sum over 100 as more than one accompanying person allowed

b"Family problems" included death of one or both parents, divorce of parents, etc.

'Other includes movement to seek healthcare, poverty, witchcraft, fear of forced marriage

Patterns of rural-urban migration differed by sex. Male migrants were more likely to come as children, with 34 percent of adolescent boys moving to Nairobi before the age of 10 compared to 19 percent of girls moving during that period. Girls were significantly more likely to move during later adolescence; 53 percent of female migrants moved to Nairobi between the ages of 15 to 19 . Likewise, boys were more likely to move with their parents; 54 percent of male migrants moved with parents compared to 39 percent of female migrants, a difference that was statistically significant. Six percent of girls moved with their husbands and one percent moved with employers. 
The most common reason for moving to Nairobi was for education or vocational training, which was cited among 41 percent of males and 40 percent of females. Many young people described the availability of vocational training or the quality of education in Nairobi:

My parents could not afford secondary school fees. My sister decided that I should come [to Nairobi] and she would pay for my vocational training as a dress maker. (Girl, age 18, migrated from Western Province at age 18 , never married, 8 years education)

My parents wanted me to learn in a well-constructed school and a better learning atmosphere. The classroom walls in Nairobi are cemented. (Boy, age 19, migrated from Western Province at age 13, never married, 7 years education)

Roughly one in seven migrants came in search of work, especially when there were hardships at home. Many of the girls described coming to Nairobi as domestic workers:

My parents are so poor that they cannot even manage to put a meal on the table. So they decided that I should come and work because, in addition to helping them with money, I can eat here. (Girl, age 14, never married, migrated from Nyanza Province at age 14, 4 years education)

A relative came home and asked me if I would like to come to Nairobi to work for one of her friends as a maid, so I accepted and came. Also, my mum accepted. (Girl, age 17, never married, migrated from Central Province at age 13, 4 years education)

Migration also occurred when parents died:

A relative came home and asked me if I would like to come to Nairobi to work for one of her friends as a maid, so I accepted and came. Also, my mum accepted. from Central Province at age 13, 4 years education
My parents had died and I had no one to take care of me. Because I was still young, my brother wanted me to be near him, to take care of me. Boy, age 19, migrated from Nyanza at age 16, never married, 8 years education)

My father had died and when I went back upcountry with my mum, I found my grandmother had distributed our property to other family members and we had nothing to call our own. (Boy, age 11, migrated from Eastern Province at age 6, never married, 5 years education) 


\section{EduCATION}

Kibera girls are significantly less likely to be attending school than boys; 43 percent of girls in the sample were out of school, compared to 29 percent of boys. At the same time, there were no significant differences between sexes in terms of educational attainment. However, in our sample of adolescents aged 10 to 19 , many young people are still in school and have not yet reached their ultimate attainment. In order to estimate ultimate attainment, we examined the educational attainment of the oldest adolescents in the sample, those aged 18 and 19. Boys do appear to have higher levels of attainment with 50 percent of boys reaching secondary level compared to only 42 percent of girls, a difference that was marginally significant, at the 0.1 level. Only about two thirds of young people reported that they can read easily and about a third reported that they read with difficulty.

Girls were less likely than boys to start school on time. Sixty one percent of school going boys started school by age 6 , compared to 49 percent of girls. When out-of-school youth were asked the main reason for leaving school, the majority of young people (59 percent of boys and 51 percent of girls) described that their families could not afford the fees. Many described completing a schooling cycle, such as primary or secondary. It is noteworthy that more girls left school due to marriage (14 percent) than due to pregnancy ( 9 percent).

Table 4: Age of school entry, educational attainment \& reason for leaving school, by sex

\begin{tabular}{|c|c|c|c|}
\hline & & Boy $(n=754)$ & Girls ( $n=921)$ \\
\hline \multirow[t]{3}{*}{ Age of school entry } & Age 6 or below & 61.3 & $48.5^{\star \star *}$ \\
\hline & Age 7 to 9 & 35.0 & 49.0 \\
\hline & Age 10 and over & 3.7 & 2.5 \\
\hline \multirow{3}{*}{ Educational attainmenta } & No education & 2.1 & $2.4 \sim$ \\
\hline & 1 to 8 years of education & 47.9 & $55.6 \sim$ \\
\hline & 9 to 13 years of education & 50.0 & 42.0 \\
\hline \multirow{7}{*}{$\begin{array}{l}\text { Main reason for leaving school } \\
\text { (among those not attending) }\end{array}$} & Family could not afford & 59.3 & 51.2 \\
\hline & Finished schooling cycle & 35.8 & 19.0 \\
\hline & Got married & 0.0 & 13.7 \\
\hline & Got pregnant & 0.0 & 8.7 \\
\hline & Family does not approve & 0.3 & 2.5 \\
\hline & Sickness/death in family & 1.2 & 1.9 \\
\hline & Other & 3.4 & 3.0 \\
\hline \multirow[t]{3}{*}{ Literacy } & Reads easily & 66.1 & 62.6 \\
\hline & Reads with difficulty & 28.3 & 31.5 \\
\hline & Does not read at all & 5.6 & 5.9 \\
\hline
\end{tabular}

${ }^{a}$ Among those aged 18 and 19; ${ }^{b}$ Among those not attending;

Differences between groups significant at $\sim p<0.1{ }^{*} p<0.05 ;{ }^{* *} p<0.01 ;{ }^{* * *} p<0.001$ 
Twenty one percent of adolescents have had vocational training (23 percent of boys and 20 percent of girls). The most common types of vocational training were trades such as carpentry, mechanics and plumbing among boys, and dressmaking among girls.

\section{LIVELIHOODS}

\section{Paid work}

Twenty-five percent of boys and 14 percent of girls have worked for pay. The most common jobs for boys were construction work or building (22 percent of working boys), tradesmen such as carpenters, masons, plumbers, electricians (16 percent), portering or carrying heavy loads (16 percent), or hawking foodstuffs or goods such as charcoal or used clothes (14 percent). Among girls, work options were much less varied than for boys. Fully 49 percent of working girls were engaged in domestic work. In addition, 18 percent of girls were working as dressmakers, and 8 percent as hairdressers.

Under Kenya's Employment Act, the legal age for industrial work is 16 . Under this act, there is no legal age for work in the agricultural sector or service sector, including domestic work, except when the work poses a danger to "life, health, or morals" (Melchiorre, 2004). Thirty seven percent of working young people started work before the legal age of 16 .

Boys were engaged in paid work for longer hours than girls; boys worked an average of 40 hours per week, compared to girls' 28 hours per week. Boys earned significantly more than girls, perhaps because they worked for a greater number of hours. Working males earned an average of KSH 756 (USD \$11) in the previous week compared to girls' KSH 595 (USD \$9), a difference that was statistically significant. In addition, boys were more likely to be able to decide how earnings were used. Nearly one out of five female workers (18 percent) was not able to decide how to spend money earned, compared to one out of 10 boys.

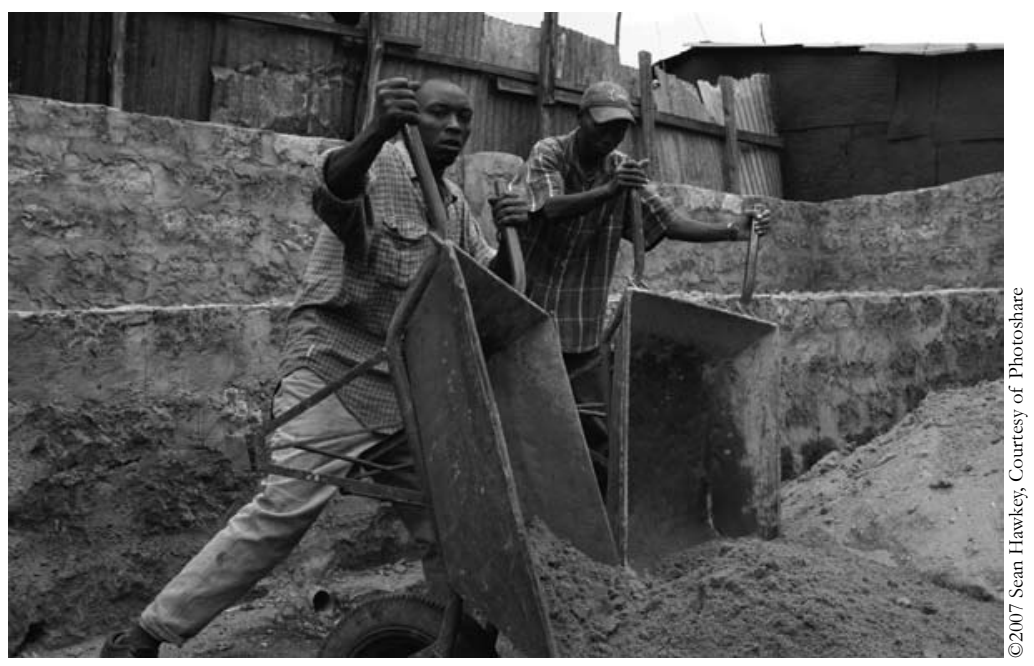


Table 5: Patterns of paid work among adolescents, by sex

Boy $(n=193)$ Girls $(n=147)$

\begin{tabular}{|c|c|c|c|}
\hline \multirow[t]{12}{*}{ Type of work } & Domestic worker & 1.3 & 49.1 \\
\hline & Building/construction & 21.6 & 0.5 \\
\hline & Hawking food/consumables & 14.3 & 4.6 \\
\hline & Porter/carrying loads & 16.3 & 0.0 \\
\hline & Tradesman & 15.6 & 0.0 \\
\hline & Tailoring/dressmaking & 1.0 & 17.6 \\
\hline & Cook/waiter/barmaid & 6.3 & 6.5 \\
\hline & Salesperson & 8.3 & 2.8 \\
\hline & Laundry/washing clothes & 0.0 & 8.8 \\
\hline & Hairdresser & 0.0 & 8.3 \\
\hline & Carwash & 3.3 & 0.0 \\
\hline & Other & 12.0 & 1.8 \\
\hline No of hours in paid & Less than 10 hours & 23.6 & 23.4 \\
\hline \multirow[t]{3}{*}{ work in the last week } & 10 to 39 hours & 19.5 & $42.6^{*}$ \\
\hline & 40 to 60 hours & 30.9 & 23.4 \\
\hline & Over 60 hours & 26.0 & 10.6 \\
\hline \multirow[t]{3}{*}{ Conditions of paid work } & Work for family member & 9.0 & 13.9 \\
\hline & Work for non-relative & 81.4 & 75.0 \\
\hline & Self employed & 9.6 & 11.1 \\
\hline Through whom paid work & Relative & 30.9 & 41.7 \\
\hline \multirow[t]{3}{*}{ was acquired } & Friend & 35.5 & 31.5 \\
\hline & Inquiries/self & 25.5 & 17.6 \\
\hline & Other ${ }^{b}$ & 8.1 & 9.2 \\
\hline \multirow{3}{*}{$\begin{array}{l}\text { Control of earning and } \\
\text { sharing with others }\end{array}$} & Keep all earnings for self & 34.6 & 33.8 \\
\hline & Keep some, give some to others & 61.1 & 62.0 \\
\hline & Give all earnings to others & 4.3 & 4.2 \\
\hline \multirow{2}{*}{$\begin{array}{l}\text { Able to decide how earnings } \\
\text { are used }\end{array}$} & No & 10.2 & $18.2^{*}$ \\
\hline & Yes & 89.8 & 81.8 \\
\hline
\end{tabular}

Differences between groups significant at ${ }^{*} p<0.05 ;{ }^{* *} p<0.01 ;{ }^{* * *} p<0.001$

a "Other" types of paid work includes factory or farm workers, security guards, sportsmen, teachers

b"Other" sources of paid work include brokers, former employer, current employer, etc. 


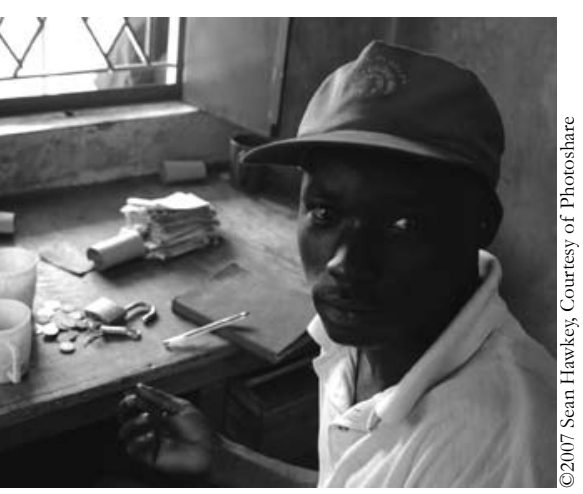

When asked if they felt their work could harm their health, 37 percent of boys and 18 percent of girls reported they felt it could. Most of the concern related to the extreme physical demands of the job, lack of protective equipment, and daily contact with chemicals or other materials:

\section{I don't have a protective mask, when I do the work, so I inhale the paint and it may harm my respiratory system. Some paints irritate me when I inhale them. (Boy, aged 16, 10 years education, working as painter) \\ I do so much housework - whether it's cold, or not - so I could develop problems. I don't find time to eat. (Girl, aged 19, no education, working as domestic worker)}

\section{Unpaid work}

While boys were engaged in longer hours of paid work, girls worked considerably longer hours in unpaid work, such as house cleaning, cooking, and washing dishes. On average, girls devoted 17 hours per week to unpaid work compared to boys' 8 hours in unpaid work.

\section{Savings}

Previous research in adolescent girls' livelihoods in Kenya has underscored the importance of savings as a safety net against economic shocks, especially among the poorest and most vulnerable adolescents (Erulkar, et. al. 2006). Only ten percent of respondents (12 percent of boys and 9 percent of girls) report having personal savings. Older adolescents are significantly more likely to have savings, as are those who have worked for pay. On average, young people began saving at age 15. Among savers, girls have set aside an average of $\mathrm{KSH} 1,488$ (USD \$21), compared to boys who have saved KSH 1,234 (USD \$17). The vast majority of young people described the purpose of their savings as, not for a specific goal or purchase, but in support of family members, including parents.

The majority of young people were saving at home: 79 percent of boys and 62 percent of girls. Many young people saved with a friend or relative (17 percent). Eight percent of girls and 2 percent of boys were saving in banks, and 6 percent of girls and 2 percent of boys were saving with savings groups. More boys than girls questioned the safety of their savings, possibly because more boys were saving at home. Twenty-six percent of boys and 20 percent of girls feared that their savings would be taken.

Boys are more likely to have control over how savings is used, compared to girls. Eighty-four percent of boys have sole control of their savings, and 16 percent make decisions jointly with relatives. In contrast 80 percent of female savers have exclusive control, 12 percent have joint control with relatives, but 8 percent have no control, whatsoever, over how their savings is used. 


\section{Social Support, Safety Nets \& Sense OF WELL-BEING}

\section{Citizenship}

In Kenya, one can get a national identity card upon reaching the age of 18. A Kenyan identity card is required for voting and by most employers in the formal sector. Anecdotally, having an identity card may protect one from being harassed or arrested by the police; those without identity cards are said to be more likely to be taken to jail when questioned by police, and more susceptible to be pressured for bribes. Among those aged 18 and above, boys are significantly more likely to have an identity card than girls. Thirty-eight percent of boys have a national identity card compared to 27 percent of girls.

\section{Sense of well-being}

Respondents were read a series of statements related to their experiences in the neighbourhood, including fear of crime and experience of harassment. Two thirds of adolescent boys and girls reported that there was a lot of crime in the neighbourhood. One out of ten reported that they had been touched indecently or molested by someone in their community. Girls were significantly more likely than boys to feel scared of rape, to fear being beaten, or to have experienced teasing.

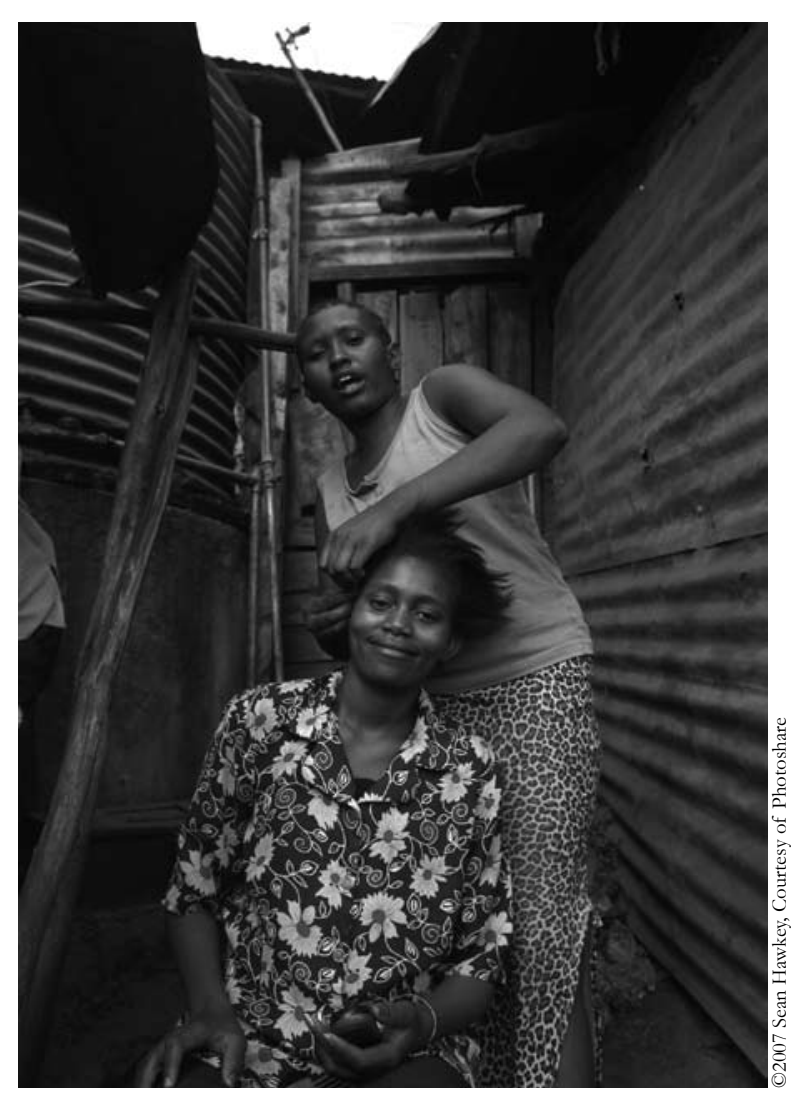

People kill each other for no reason. Like this week, nearly seven people have been killed in this area and they didn't do anything wrong. - Girl, age 11, in school, 4 years education 
Table 6: Sense of well- being in the community, by sex

Boy $(n=754) \quad$ Girls $(n=921)$

There is a lot of crime in your neighbourhood

65.5

67.0

At times, you feel scared that you will be raped

18.6

$59.6^{* * *}$

You are scared of being beaten by someone in your neighbourhood

36.1

$47.1^{* * *}$

In your neighbourhood, people of the opposite sex tease you as you go about your business

25.1

$30.4^{* *}$

You have been touched indecently by someone in your neighbourhood

11.4

12.8

Differences between groups significant at ${ }^{*} p<0.05 ;{ }^{* *} p<0.01 ;{ }^{* * *} p<0.001$

\section{Social support \& safety nets}

We read a series of statements related to support networks available to respondents in their community. Statements related to locations in the community to meet friends, including places they perceived of as "safe." Statements also referred to sources of social support including a place to stay in an emergency, a loan in case of pressing needs, and an adult in the community to whom one could turn.

On all aspects related to community networks and social support, boys were significantly more likely to have a safe place in the community or to have sources of support, compared to girls. Two thirds of boys reported that they had many friends in the community compared to 50 percent of girls. Two thirds of boys reported having a place to meeting same sex friends compared to only one third of girls. Only one quarter (25 percent) of girls mentioned that there is a place in their community outside of home or school that they feel safe, compared to 58 percent of boys.

When adolescents experience emergencies, boys are significantly more likely to have a place to turn than girls. Fifty-one percent of boys reported they had a place to stay compared to 38 percent of girls; 38 percent of boys had someone from whom they could borrow money compared to 33 percent of girls. More boys than girls had an adult they could turn to for help (53 percent of boys and 40 percent of girls).

When young people were asked what they most liked about Nairobi, the most common responses related to the quality and proximity of schools, as well as to lessened workload compared to their rural homes:

I like Nairobi because of the schooling. In rural areas, you go to school
without eating anything and without shoes, but in Nairobi you eat, you
wear a good uniform, and have shoes. (Boy, aged 11, in school, five years
education)

When asked what they do not like about Nairobi, the vast majority talked about violence, including ethnic clashes: 
People kill each other for no reason. Like this week, nearly seven people have been killed in this area and they didn't do anything wrong. (Girl, age 11, in school, 4 years education)

I don't like slum clashes where a lot of people get killed. The last time my friend's parents were injured in the clashes. (Boy, age 13, in school, 7 years education)

Kibera is a place where there is a lot of violence. For instance, thieves break in your house; they tell you to kneel down and they start taking away your belongings. If you scream, they can decide to shoot you - this makes me hate this place. (Girl, age 19, out of school, 8 years education, married at age 17)

A number of girls described the threat of rape:

So many young girls are raped everyday. I hate it so much because I live in fear. Recently, a 12 year old schoolmate of mine was raped. (Girl, age 10, in school, 4 years education)

Little girls are raped everywhere. Whenever I watch news in my aunt's bouse, I see that girls are being raped and infected with HIV/AIDS.

(Girl, age 12, in school, 5 years education)

Young people were read a series of statements related to their self perception and outlook for the future. Fully one third of young people reported that, at times, they feel worthless and roughly the same number said they have no hope for the future. Girls were significantly less likely to feel as intelligent as others, with one out of four girls not feeling as intelligent as her peers.
So many young girls are raped everyday. I hate it so much because I live in fear. Recently, a 12 year old schoolmate of mine was raped. - Girl, age 10, in school, 4 years education

Table 7: Social support and networks in the community, by sex

\begin{tabular}{lcc}
\hline & Boy ( $\mathrm{n}=\mathbf{7 5 4})$ & Girls (n=921) \\
\hline $\begin{array}{l}\text { You have many friends in your neighbourhood } \\
\text { There is a place other than your house, your friend's house or school, where }\end{array}$ & 69.9 & $50.1^{* * *}$ \\
you meet your friends of the same sex & 67.0 & $36.3^{* * *}$ \\
$\begin{array}{l}\text { There is a place in the community, other than your house, your friend's house or } \\
\text { school, where you feel safe to meet your same sex friends }\end{array}$ & 58.3 & $25.3^{* * *}$ \\
$\begin{array}{l}\text { There is a same sex adult in your community, other than your parents or teacher, } \\
\text { who you could turn to if you had a serious problem }\end{array}$ & 52.5 & $39.6^{* * *}$ \\
$\begin{array}{l}\text { If you didn't have a place to stay, there is someone in your neighbourhood who } \\
\text { would take you in }\end{array}$ & 50.9 & $38.2^{* * *}$ \\
$\begin{array}{l}\text { If you needed money urgently, there is someone in your neighbourhood who you } \\
\text { could borrow money from }\end{array}$ & 37.6 & $32.7^{* *}$ \\
\hline
\end{tabular}

Differences between groups significant at ${ }^{*} p<0.05 ;{ }^{* *} p<0.01 ;{ }^{* * *} p<0.001$ 
Table 8: Self esteem, by sex

Boy $(n=754) \quad$ Girls $(n=921)$

\begin{tabular}{lll}
\hline You feel as intelligent as most other young people your age & 89.1 & $76.8^{\star * *}$ \\
You sometimes feel worthless & 35.3 & 38.5 \\
You don't have hope for your future & 33.4 & 31.2 \\
\hline
\end{tabular}

Differences between groups significant at ${ }^{*} p<0.05 ;{ }^{* *} p<0.01 ;{ }^{* * *} p<0.001$

\section{Sexual Behaviour}

Thirty-two percent of boys and 36 percent of girls have had sexual intercourse; among unmarried adolescents in the sample, 31 percent of boys and 24 percent of girls are sexually experienced. Ninety-nine percent of boys first had sex premaritally, compared to 88 percent of girls, a difference that was statistically significant. On average, boys' first sexual partners were only slightly younger than themselves ( 0.3 years), while girls' first partners were an average of 4 years older than themselves. Among girls who first had sex with their husbands, the mean age difference was 6 years, while those who had sex with boyfriends, friends or acquaintances, had a mean age difference of 3.2 years with their first partner.

Boys were significantly more likely to have wanted to have sex when they did, compared to girls. Sixty-one percent of boys' first sex was wanted, compared to only 34 percent of girls. Fully 34 percent of girls did not want to have sex when they did and 32 percent were undecided.

Table 9: Relationship to and age difference with first sexual partner, by sex

\begin{tabular}{lcc}
\hline & Boy $(\mathrm{n}=\mathbf{2 6 0})$ & Girls ( $\mathbf{n}=\mathbf{3 6 9})$ \\
\hline Relationship to first sexual partner & & \\
Boyfriend/girlfriend & 74.7 & 75.4 \\
Spouse/fiancé & 0.5 & 14.6 \\
Friend & 13.3 & 3.9 \\
Acquaintance/ neighbor & 7.5 & 5.0 \\
Stranger & 4.0 & 0.5 \\
Relative & 0.0 & 0.7 \\
& & \\
Age difference with first sexual partner & & \\
Partner is 5+ years younger & 0.6 & 1.4 \\
Partner is 1 to 4 years younger & 50.4 & 1.0 \\
Partner is same age & 29.9 & 1.9 \\
Partner is 1 to 4 years older & 17.7 & 67.7 \\
Partner is 5 to 9 years older & 9.9 & 23.8 \\
Partner is 10+ years older & 0.6 & 4.1 \\
\hline
\end{tabular}


Respondents were read issues that may motivate one to have sex for the first time, such as to show love or satisfy curiosity, and asked if the situation applied to them. The majority of boys mentioned that they had first sex because of curiosity ( 72 percent), while 46 percent of girls mentioned the same reason. A considerable proportion of girls (43 percent) were coerced or forced into their first sex, including the partner not taking 'no' for an answer, being threatened, promised money/gifts, or being physically forced. Girls who were coerced had first sex at significantly younger ages than those who were not. On average, girls who were coerced into first sex had sexual initiation at age 14.9, compared to non-coerced girls who had first sex at age 15.7.

Some respondents reported both positive motivations for sex (such as, to show love or out of curiosity) as well as negative motivations for sex (insistence or threats). For example, among girls who reported being curious about sex, 27 percent also reported that their partner insisted; this possibly implies that girls who were curious may be relatively more amenable to pressure.

Boys have had considerably more sex partners than girls, with boys having had an average of 3.5 lifetime partners, compared to girls' 1.7 partners. Among sexually experienced youth, sex was nonetheless sporadic. Only 37 percent of sexually active boys had had sex in the month prior to survey, and 29 percent of unmarried sexually active girls had sex in the previous month. In contrast, 80 percent of married girls in the sample had had sex in the last month.

Table 10: Context of first sexual experience, by sex

Boy $(n=260) \quad$ Girls $(n=369)$

\begin{tabular}{lcc}
\hline "Wantedness" of first sex & & \\
Wanted first sex & 61.3 & $33.5^{\star * *}$ \\
Did not want first sex & 9.6 & 34.2 \\
Was undecided & 29.1 & 32.3 \\
& & \\
Motivation for first sex & & \\
To show love & 48.0 & 42.9 \\
Curiosity & $72.0^{* * *}$ & 46.1 \\
Partner insisted/ would not take 'no' for an answer & 13.1 & $34.9^{\star * *}$ \\
Threatened & 0.5 & $5.9^{* * *}$ \\
Promised money/gifts & 1.6 & 3.7 \\
Physically forced & 0.5 & $6.7^{\star * *}$ \\
Any form of coercion (insistence, threats, money, force) & 14.9 & 43.3 \\
\hline
\end{tabular}

Differences between groups significant at ${ }^{*} p<0.05 ;{ }^{* *} p<0.01 ;{ }^{* *} p<0.001$ 


\section{Marriage \& Attitudes Related to MARRIAGE}

\section{Context of marriage}

Sixteen percent of girls and 2 percent of boys have ever been married or cohabitated. Only two male respondents reported having been divorced. Table 11 shows the conditions under which girls were married. ${ }^{1}$ Most marriages were chosen and not arranged; parents were involved in only 11 percent of girls' marriages. Eighty-five percent of girls knew their spouse before marriage and 94 percent consented to the marriage. Over 60 percent considered that the timing of their marriage was too early; however, among these, 61 percent wanted to get married at the time, probably reflecting that the perceived mistiming of marriage was in hindsight.

All married girls were younger than their spouses. On average, married girls were 6.4 years younger than their spouse. Nearly half of married girls were 6 to 10 years younger than their spouse.

Table 11: Conditions of marriage among girls

\begin{tabular}{lc}
\hline & Married girls ( $\mathbf{n}=\mathbf{2 0 2})$ \\
\hline Knew spouse before marriage & 85.0 \\
Wanted to get married at the time they did & 74.1 \\
& \\
Consented to the marriage & 93.5 \\
& \\
Views on timing of marriage & 62.3 \\
Too early & 0.0 \\
Too late & 37.7 \\
At the right time & \\
& \\
Age difference with spouse & 19.1 \\
1 to 3 years younger & 23.9 \\
4 to 5 years younger & 47.3 \\
6 to 10 years younger & 9.7 \\
Over 10 years younger & \\
\hline
\end{tabular}

\section{Risk within marriage}

Regarding decision-making related to sex, about two thirds (62 percent) of married girls report that sex is a joint decision and 34 percent say that the decision is made by the husband. Forty percent of girls are not able to refuse their spouse sex.

${ }^{1}$ There were too few married boys in the sample to include in analysis. 
Ten percent of married girls admitted they had not always been faithful to their spouses. When asking girls about their husband's infidelity, many were not sure if their husband had always been faithful. Nine percent reported that their husbands had definitely not been faithful, while 23 percent were not sure, likely reflecting girls' suspicion of infidelity. Despite high rates of infidelity, real or suspected, few girls were able to insist on condom use; only 37 percent of married girls were able to use a condom with their husbands when they wanted.

There were high rates of domestic violence; one in six married girls had been hit or beaten in the past three months. When asked the reasons for the beating, most married girls said that they had talked rudely to their husbands or disobeyed them, and many described instances where children were crying, food or clothes were spoilt, or domestic work not done. Some described finding their husband with another woman or husbands coming home drunk.

He told me to get him water for bathing and I forgot so he got angry. When he found me talking to another woman and I hadn't done what be told me to, [he beat me]. (Female, age 19, married at age 14 to 25 year old man, never attended school)

I had gone to see a sick friend and I left him to take care of the child. I thought I would take three hours but I took five hours. So he was mad and bit me. (Female age 19, married at age 18 to 25 year old man, 8 years of education)

One formerly married boy described the beatings he used to give his exwife as spurred on by lack of respect:

She did not know how to answer me with respect. She was arrogant towards me. (Male, age 19, married at age 19 to a 15 year old girl, 8 years education)

Table 12: Risk taking and infidelity within marriage

\begin{tabular}{lc}
\hline & Married girls ( $\mathbf{n = 2 0 2 )}$ \\
\hline Spouse has had other wives/girlfriends (yes or not sure) & 31.6 \\
Respondent has always been faithful & 90.7 \\
Has been hit or beaten by husband in last three months & 16.6 \\
Not able to insist on condom use & 63.3 \\
Worries that spouse will give her HIV & 37.2 \\
\hline
\end{tabular}

I had gone to see a sick friend and I left him to take care of the child. I thought I would take three hours but I took five hours. So he was mad and hit me.

- Female age 19, married at age 18 to 25 year old man, 8 years of education 
[I wanted to leave my husband] because of the girlfriend he has.

At the same time,

I fear contracting AIDS which is likely to be brought to my house by my husband, as I am faithful.

- Girl, aged 18, married at age 17 to 24 -year old man, 5 years education
Over one third (37 percent) of married girls worried that their spouse could give them HIV. Girls who knew about or suspected infidelity were significantly more likely to worry about HIV infection from their husbands. Among girls who suspected infidelity, 55 percent worried about getting HIV from husbands, compared to 29 percent of wives who did not suspect infidelity. Forty eight percent of married girls who have been beaten worry their spouse will give them HIV, compared to 35 percent of girls who have not been beaten.

[I wanted to leave my husband] because of the girlfriend he has. At the same time, I fear contracting AIDS which is likely to be brought to my house by my husband, as I am faithful. (Girl, aged 18, married at age 17 to 24-year old man, 5 years education)

I'm not sure, but I think he may be having an affair since be comes home very late, yet he doesn't drink. And he doesn't want to be asked where he was [when he comes home late]. (Girl age 19, married at age 18 to 25-year-old man, 8 years education)

\section{Attitudes about marriage}

All adolescents - whether married or unmarried - were read a series of statements related to marital relationships. On the vast majority of statements, girls held more liberal views toward marital relationships than did boys. Two thirds of boys felt that wives should defer to the man's opinion in case of disagreements; 58 percent of boys felt that it is a man's right to refuse to let his wife see her friends. Half of the boys and 29 percent of the girls felt that a girl is more protected from HIV once she gets married.

Table 13: Percent of respondents holding conservative views related to marriage, by sex (percentage agreeing with the statement)

\begin{tabular}{lcc}
\hline & Boy (n=754) & Girls (n=921) \\
\hline If a woman differs with her husband, she must accept his opinion & 66.7 & $39.8^{* * *}$ \\
It is better if the husband has more education than his wife & 65.9 & $44.7^{* * \star}$ \\
It is a man's right to refuse to allow his wife to go out with her friends. & 57.8 & $35.5^{* * *}$ \\
It is a wife's duty to have sex with her husband whenever he wants to have sex & 54.5 & $37.8^{* * *}$ \\
A husband should be able to refuse sex to his wife & 46.5 & $29.0^{* * \star}$ \\
A girl is more protected from HIV if she gets married & 49.4 & $30.2^{* * *}$ \\
A married girl should not go to school & 43.4 & 42.9 \\
It is better when a girl's family selects her husband, rather than she selecting herself & 25.6 & $18.6^{* * *}$ \\
If a husband doesn't beat his wife, it means he doesn't love her & 11.0 & 9.7 \\
It is OK for a man to beat his wife if she burns the food & 6.2 & $10.8^{* * *}$ \\
\hline
\end{tabular}

Differences between groups significant at ${ }^{*} p<0.05 ;{ }^{* *} p<0.01 ;{ }^{* * *} p<0.001$ 


\section{HIV/AIDS, Reproductive Health \& Family Planning}

\section{Knowledge of HIV/AIDS \& STIs}

When asked to name modes of HIV transmission, 88 percent of boys and 91 percent of girls mentioned unprotected sexual intercourse. Conversely, 7 percent of boys and 6 percent of girls could not name one mode of HIV transmission.

Respondents were read a series of statements related to HIV transmission in order to assess knowledge levels. About three quarters of young people knew that there is no cure for AIDS and that a healthy looking person can be infected with HIV. Knowledge on the effectiveness of condoms and whether or not a condom can get lost inside a woman was significantly lower. Only 41 percent of boys and 32 percent of girls knew that condoms were effective in preventing HIV transmission; only 36 percent of boys and 23 percent of girls knew that condoms cannot get lost inside a woman's body. Likewise, knowledge about sexually transmitted infections (STI) was low; only one in five respondents knew that women could not always tell when they were infected with an STI.

Table 14: HIVIAIDS and RH knowledge, by sex

Boy $(n=754) \quad$ Girls $(n=921)$

Know that there is no cure for AIDS

78.3

75.4

Know that a healthy looking person can be infected with HIV

Know that one cannot get AIDs from sharing eating utensils such as knives and forks

Know that a woman cannot always tell when a man has a sexually transmitted infection

Know that condoms are effective in preventing HIVIAIDS

$40.8^{* * *}$

Know that most people do not get AIDS from accidents with sharp instruments.

Know that withdrawal does not protect from HIV infection

Know that a condom cannot get lost inside a woman's body

Know that a woman cannot always tell if she (herself) has a sexually transmitted infection 


\section{Family planning knowledge and use}

Respondents were read a list of family planning methods and asked if they had ever heard of the method. Eighty one percent of boys and 71 percent of girls had heard of at least one family planning method.

Table 15: Knowledge ${ }^{2}$ of family planning methods, by sex

\begin{tabular}{lcc}
\hline & Boy $(\mathbf{n}=\mathbf{7 5 4})$ & Girls $(\mathrm{n}=\mathbf{9 2 1})$ \\
\hline Know any family planning method & $\mathbf{8 1 . 2 ^ { * * * }}$ & $\mathbf{7 1 . 3}$ \\
Pills & 33.6 & $46.1^{* * *}$ \\
IUCD & 10.7 & $18.6^{* * *}$ \\
Injectable/Depo & 19.5 & $41.5^{* * *}$ \\
Male condom & $78.7^{* * *}$ & 67.8 \\
Female condom & 36.8 & 36.1 \\
Norplant & 9.9 & $20.5^{* * *}$ \\
Emergency contraceptives & $16.1^{* * *}$ & 10.9 \\
Post partum abstinence & $22.2^{* * *}$ & 12.0 \\
Safe days & 25.2 & 25.2 \\
Breastfeeding & 12.9 & 10.8 \\
\hline
\end{tabular}

Differences between groups significant at ${ }^{*} p<0.05 ;{ }^{* *} p<0.01 ;{ }^{* *} p<0.001$

When asked if they or their partners had ever used a family planning method, 53 percent of sexually active boys and 56 percent of girls had ever used a method. Use of methods other than condoms among boys appears low and this may be due to boys not knowing that their partners are using a method. Among girls, the most common methods were condoms (37 percent), followed by injectables (19 percent), and pills (17 percent). Fully one out of 10 girls had used safe days which is not a reliable method and does not protect against sexually transmitted infections.

Table 16: Ever use of family planning methods, by sex

\begin{tabular}{lcc}
\hline & Boy $(\mathrm{n}=\mathbf{2 6 0})$ & Girls $(\mathrm{n}=369)$ \\
\hline Ever used a family planning method & $\mathbf{5 3 . 1}$ & $\mathbf{5 6 . 4}$ \\
Pills & 1.3 & $16.7^{* * *}$ \\
IUCD & 0.5 & $5.9^{* * *}$ \\
Injectable/Depo & 1.6 & $19.0^{* * *}$ \\
Male condom & $50.4^{* * *}$ & 37.4 \\
Female condom & 1.1 & $5.3^{* * *}$ \\
Norplant & 0.5 & $4.4^{* * *}$ \\
Emergency contraceptives & 0.0 & $4.1^{* * *}$ \\
Safe days & 3.5 & $9.9^{* * *}$ \\
\hline
\end{tabular}

Differences between groups significant at ${ }^{*} p<0.05 ;{ }^{* *} p<0.01 ;{ }^{* * *} p<0.001$

${ }^{2}$ Respondents were read a list of methods and asked if they had heard about particular methods. Therefore, these are probed responses and may be an overestimate of actual knowledge levels. 


\section{Sexually transmitted infections}

Five percent of boys and six percent of girls report having had a sexually transmitted disease, either diagnosed or suspected. A large proportion of girls did not seek treatment (52 percent) compared to 20 percent of boys reporting not doing anything. Those who sought treatment reported going to a clinic or hospital.

\section{Experience with HIV/AIDS}

Twenty-seven percent of girls and 25 percent of boys have had a member of their family die of HIV/AIDS. Twenty-nine percent of girls and 14 percent of boys report having undergone VCT. Young people who had never had VCT but reported wanting the test, were asked the main reason why they had never gone for the test. The most common reason given was fear of the outcome, mentioned by 29 percent of respondents. After that, common reasons for not having VCT when they wanted it were that they did not know where to get the test (10 percent), that they had no time (10 percent), or they considered themselves too young ( 7 percent).

Table 17: Experience with HIVIAIDS and knowledge and exposure to VCT, by sex

\begin{tabular}{lll}
\hline & Boy $(\mathbf{n}=\mathbf{7 5 4})$ & Girls $(\mathbf{n}=\mathbf{9 2 1})$ \\
\hline $\begin{array}{l}\text { Know of someone who has suffered } \\
\text { from or died from HIVIAIDS }\end{array}$ & 34.4 & $38.8^{*}$ \\
Had a family member who has died of HIVIAIDS & 25.4 & 27.2 \\
Worry at times that they are HIV positive & 25.5 & 27.5 \\
Know where to get an HIV test/ VCT & $72.5^{* *}$ & 67.5 \\
Ever had VCT & 14.2 & $29.4^{* * *}$ \\
Ever wanted to have VCT & 40.7 & 41.7 \\
Heard about anti-retroviral therapy & 41.7 & 39.9 \\
Know where to get anti-retroviral therapy & 24.3 & 24.1 \\
\hline
\end{tabular}

Differences between groups significant at ${ }^{*} p<0.05 ;{ }^{* *} p<0.01 ;{ }^{* * *} p<0.001$ 


\section{Discussion \& Implication for Programs}

Results of this research are meant to inform context-appropriate programs for adolescents in low income and slum areas of African cities. The most pronounced findings relate to the significant differences in the adolescent experience across gender lines. In addition, adolescents in these settings experience a considerable amount of violence and threats to safety, with many - particularly girls - having limited support networks or safety nets.

\section{Recognize the diversity of young people}

Current programming for adolescents and youth in sub-Saharan Africa is largely gender-blind and generic, and pays little attention to youth in differing circumstances, especially the most vulnerable. Few programs are tailored to the special circumstances of slum-dwelling adolescents. Further, these data suggested that, even within a limited urban geographical area, the adolescent experience is remarkably diverse.

Only a minority of young people were living with two parents, many were in single family households, and a considerable number were on their own. Yet programming for youth often emphasizes parent-child communication, overlooking the fact that many youth are not with parents in the first place. About half of the youth in the sample were not native to Nairobi but had migrated into the city. Migrants, especially girls, were often without parents or other close family members, and may have little understanding of the mechanics of life in dense and dangerous urban settings. Programs need to respond to this diversity of circumstances and experiences, with increased targeting and segmentation of the target groups, particularly those most vulnerable and in need of support.

\section{Create safety nets, addressing personal security and social support}

This study underscored the everyday threats to young people's safety and well-being in their own environment. Even at relatively young ages, adolescents in our sample had witnessed a considerable amount of violence in their neighborhoods and lived their daily lives in fear of being victims. Adolescent girls, in particular, experience violence, molestation, coercion and rape. Forty-three percent of girls had coerced or forced first sex. An alarming percentage of married adolescents had experienced domestic violence. At the same time, girls' support and safety networks are extremely thin. Girls were significantly less likely to have a nonfamilial adult they could turn to, and less likely to have a place to stay in an emergency or someone from whom they can borrow money. Research in other settings has suggested that girls with thin safety nets may be more vulnerable to coerced or forced sex, compared to girls with more social capital (Hallman and Diers, 2004). 
Programs should address the lack of social capital and safety among the most vulnerable youth, especially girls. Strategies may include increasing their access to mentors, increasing options for safe meeting spaces, especially in dense urban environments, and raising awareness on the safety and protection needs of girls.

\section{Address lack of power and agency in sexual relationships}

Many programs focus on increasing knowledge levels of young people related to such issues as HIV/AIDS or reproductive health. Our data suggest that many young people have no choice whether or not to have sex, and whether or not to protect themselves. Forty-three percent of girls experienced forced or coerced first sex; 32 percent of married adolescent girls know or suspect that their husband is not faithful and 63 percent are not able to insist on condom use within the marital relationship. Sixteen percent of married girls have been beaten by their husbands in the last three months. Programs should address power dimensions of sexual relationships, including support mechanisms to young women who are victims of domestic or sexual violence.

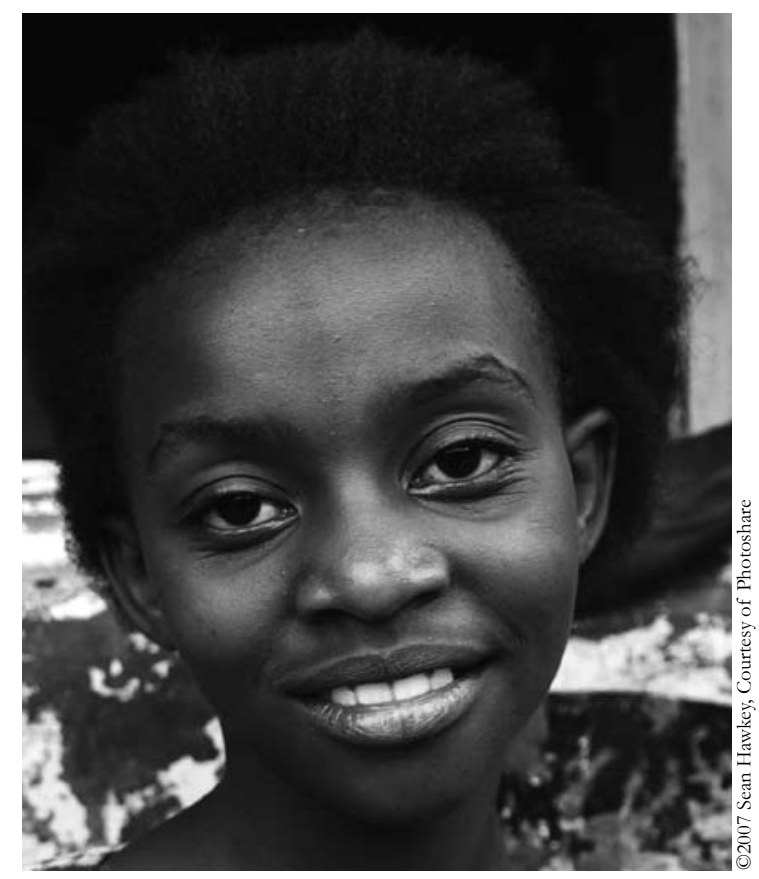




\section{REFERENCES}

African Population and Health Research Center (APHRC) 2002. Population and Health Dynamics in Nairobi's Informal Settlements. Nairobi: African Population and Health Research Center.

Erulkar AS, Bruce J, Dondo A, et al. 2006. "Tap and Reposition Youth (TRY): Providing Social Support, Savings, and Micro-credit Opportunities for Young Women in Areas with High HIV Prevalence," SEEDS Documentation Series, No. 23, January.

Garenne M. 2003. Migration, Urbanization, and Child Health in Africa: A Global Perspective, paper prepared for Conference on African Migration in Comparative Perspective, Johannesburg, South Africa, June 2003.

Hallman K, Diers. J. "Social Inclusion and Economic Vulnerability: Adolescent HIV and Pregnancy Risk Factors in South Africa," paper presented at the annual meeting of the PAA, Boston, MA, 2004.

Kish L, Survey Sampling, New York: Wiley, 1965.

Melchiorre, Angela. 2004. At what age...are school children employed, married, and taken to court? (2nd edition), Right to Education Organization.

Zulu E, Ezeh A, Dodoo F. 2000. "Slum residence and sexual outcomes: Early findings of causal linkages in Nairobi, Kenya," African Population and Health Research Center Working Paper No. 17. Nairobi: APHRC. 

